\title{
Effects of Measures of Emotional Intelligence on the Relationship between Emotional Intelligence and Transformational Leadership
}

\author{
Ljerka Hajncl \\ Institute for Assessment, Professional Rehabilitation and Employment of \\ Persons with Disabilities, Osijek, Croatia \\ Dario Vučenović \\ University of Zagreb, Faculty of Croatian Studies, Zagreb, Croatia
}

\begin{abstract}
The major purpose of the present study was to investigate the relationships between two measures of emotional intelligence: performance-based ability test, self-reported measure of ability emotional intelligence, and transformational leadership. Base on a sample of 177 middle-level and low-level leaders, in 16 organizations, the study tries to explain the role of emotional intelligence in the variance of transformational leadership style, after controlling for cognitive ability and five factors of personality. Vocabulary Emotion Test (VET-3), representing performance-based ability test of emotional intelligence, and Emotional Skills and Competence Questionnaire (ESCQ-45), representing self-report measure of emotional intelligence, $T N-10$ test of fluid intelligence and $B F I$ - inventory of personality traits were administered to all supervisors in identifying their emotional intelligence, cognitive ability and personality traits. To evaluate the transformational leadership style, the short version of a Multifactor Leadership Questionnaire (MLQX5) was used for 177 selfratings. The results show that VET-3 as the measure of ability EI has no relationship with transformational style. The results obtained in hierarchical regression analysis of self-ratings transformational leadership show that the personality traits were significant predictors but that selfreport measure of EI incrementally explained 5\% of the variance of transformational leadership.
\end{abstract}

Keywords: performance-based ability test of emotional intelligence, self-reported scale of emotional intelligence, transformational leadership

\section{Introduction}

Emotional intelligence (EI) is defined as a mental potential that relates to the interaction between emotion and cognition as well as the regulation of self,

Ljerka Hajncl, Institute for Assessment, Professional Rehabilitation and Employment of Persons with Disabilities, Tadije Smičiklasa 2, 31000 Osijek, Croatia. E-mail: ljerka.hajncl@os.ht.hr 
individually or vis-à-vis others (Salovey \& Mayer, 1990). Mayer, Caruso, and Salovey $(1999,2004)$ posited that EI comprises four abilities allowing an individual to (1) perceive, (2) use, (3) understand, and (4) manage emotions. There have been many of interest in measuring individual differences in such mental potential (Hajncl \& Vučenović, 2013). Ciarrochi, Caputi, and Mayer (2003) categorized measures of EI into one of three categories: self-report personality measures (e.g., How frequently do you experience sadness?), performance-based ability test (e.g., Identify the similar meaning of target word of emotional state.; Takšić, Harambašić, \& Velemir, 2004b), and self-report measures of ability to understand one's own emotions (e.g., I am able to maintain a good mood even if something bad happens.; Takšić, 1998). Similarly, Joseph and Newman (2010) classified EI measures into three categories: performance-based, self-report ability measures and self-report mixed models. In the study, the two measures of EI: ability-based and self-report ability measures operationalized from Mayer and Salovey's theory of EI were applied. Self-report measure and an ability conception of EI provide alternative theoretical frameworks for the operationalization of EI construct. The ability-based measures have the advantage of representing an individual's maximal performance (Hajncl \& Vučenović, 2013). In this framework, several instruments of EI were constructed in Croatia. Some of them are Vocabulary of Emotion Test-3 (VET-3; Takšić, Harambašić, \& Velemir, 2004a), Analyzing Emotions Test (AET; Kulenović, Balenović, \& Buško, 2000), and Test of Emotional Understanding (TEU; Mohorić, 2012). On the other side, self-report measures have reflected a person's self-concept or typical performance. The most frequently used self-report measure in Croatia is the Emotional Skills and Competence Questionnaire-45 (ESCQ-45; Takšić, 1998). All the instruments have shown appropriate reliabilities and various kind of validities (Mohorić \& Takšić, 2016).

Transformational leadership (TL) is explained as a set of leaders' characteristics, aims to influence employees' behaviours for the sake of achieving the organization's objectives (Bass, 1997; Lam \& O'Higgins, 2013). According to Bass's theory of leadership, TL style has five dimensions: Inspirational Motivation (IM), Intellectual Stimulation (IS), Individual Consideration (IC), and Idealized Influence (IB) (behavioural-based and attributed based). The transactional style involves Contingent Rewards (CR), Management-by-Exception Active (MEA) and Management-by-Exception Passive (MEP). Passive or laissez-faire style (LS) is the avoidant, not an active leadership behaviour (Bass, 1985, 1997). Researches find that the components of TL are conceptually related to many personality traits (Judge \& Piccolo, 2004). Some authors find it is likely that ability and competences called EI refer to, in large part, the capacity to TL (Bass, 1997, 2000; Brown \& Moshavi, 2005; Clarke, 2010; Cooper \& Sawaf, 1997; George, 2000).

The general purpose of the present study was to investigate the relationships between EI developed and conceptualized by Mayer and Salovey (1997) and TL style according to Bass's transformational theory of leadership (Bass, 1990). The 
previous results show that most studies which used self-report measure of EI provide empirical support of the relationship of EI and TL (Butler \& Chinowsky, 2006; Coetzee \& Schaap, 2005; Jordan, Ashkanasy, Hartel, \& Hooper, 2002; Mandell \& Pherwani, 2003; Spano-Szekely, Quinn Griffin, Clavelle, \& Fitzpatrick, 2016; Wong, Wong, \& Law, 2007). Using both kinds of measures, other find variances identifying subfactors of EI and TL that further explicate the EI - TL relationship (Barling, Slater, \& Kelloway, 2000; Clarke, 2010; Groves, 2006; Küypers \& Wiebler, 2006; Leban \& Zulauf, 2004; Webb, 2004). The findings of the third group of studies suggest that the ability perspective of EI does not have any relationship with TL style (Chatterjee \& Kulakli, 2015; Weinberger, 2004). The remaining studies are found to be sceptical, not fundamentally denying the relationship, but commonly pointing out the problem with EI measures and emphasizing the need for more valid and reliable assessment tools (Kim \& Kim, 2017). Although there have been a number of studies conducted assessing the role of EI in TL, very few have been conducted using each of the different measures of EI (Harms \& Credé, 2010).

Costa, Faria, and Takšić (2016) agree that the problem of the validity of different EI measures is evident but note that this area of research is only in its early stages and that researchers and authors of EI measures face the challenge of finding criteria for evaluating validity. Consequently, more research needs to be conducted to assess the validity and ability-based measures of EI as compared to self-report measures. Furthermore, in rare cases was EI tested for incremental validity above and beyond measures of intelligence and personality, and some of that kind of previous research has demonstrated that the ability-based measures of EI fail to add validity beyond such measures (Antonakis, 2004; Antonakis, Ashkanasy, \& Dasborough, 2009).

Because of the inconsistency in prior findings, the first purpose of the current study is to evaluate how EI predicts TL style using two measures of EI simultaneously. The second purpose of this research is to investigate whether EI incrementally predicts TL style after controlling for personality traits and cognitive intelligence. According to the theoretical approach and most of the previous empirical results, we propose that there would be a significant and positive correlation between perceiving, expressing and managing emotions operationalized as self-report measure and TL style (as perceived by leaders) after controlling cognitive ability and personality traits. There would be a significant (but lower than EI measure as a self-report) positive correlation between EI measure as ability and TL style as perceived by leaders after controlling for cognitive ability and personality traits. 


\section{Method}

\section{Participants}

The research was conducted in the 16 different profit and nonprofit organizations based in Osijek city (Croatia). Sample of 177 low and middle management leaders have participated in the study. Results are presented in Table 1.

Table 1

Age, Gender and Level of the Participant's Education

\begin{tabular}{|c|c|c|c|c|}
\hline \multicolumn{5}{|c|}{ Age of the participants } \\
\hline$N$ & Min & Max & $M$ & $S D$ \\
\hline 177 & 26 & 65 & 45.66 & 10.13 \\
\hline \multicolumn{5}{|c|}{ Level of the participant's education } \\
\hline$N$ & High school & Bachelor's degree & Master's degree & $\mathrm{PhD}$ \\
\hline 177 & 52 & 73 & 50 & 2 \\
\hline \multicolumn{5}{|c|}{ Gender of the participants } \\
\hline & & Male & & \\
\hline & & $77(43.5 \%)$ & $6.5 \%)$ & \\
\hline
\end{tabular}

\section{Instruments}

Emotional Skills and Competence Questionnaire (ESCQ-45, Takšić 1998; Takšić, Mohorić, \& Duran, 2009) was developed in the Croatian settings using the theoretical framework from the Mayer and Salovey emotional intelligence model (Mayer \& Salovey, 1997) as the self-reported measure of ability EI. The ESCQ-45 consists of 45 items, divided into three subscales, which measure: the ability to Perceive and Understand emotions (e.g., I notice when somebody feels guilty.), the ability to Express and Label emotions (e.g., I am able to express my emotions well.) and the ability to Manage and Regulate emotions (e.g., I do not have difficulty to persuade a friend that there is no reason to worry.). The ESCQ-45 is used in many studies and has shown satisfying psychometric characteristics. It was translated and validated in several countries (Avsec, Takšić, \& Mohorić, 2009; Faria et al., 2006; Molander, Holmström, \& Takšić, 2011; Takšić, Mohorić, \& Holmström, 2018). In different cross-cultural studies, the ESCQ-45 was applied to a large sample of university students, confirming the three-factor structure. Reliability for the Perceive and Understand emotions factor were $.82-.88$; for the ability to Express and Label emotions $.78-.81$ and for the ability to Manage and Regulate emotions $.68-.72$. The correlation between subscales was .35 - .51 which allows forming a general measure of emotional competence with reliability between .87 and .92 (Takšić, 2002).

Vocabulary Emotions Test (VET-3, Takšić et al., 2004a) was developed within Mayer and Salovey conceptualization of EI and represents a measure of ability from 
branch C: the understanding of emotions. In this study, a first version of the test consisted of 102 adjectives describing various emotional states and moods, was applied. The first adjective is the target word, followed by six adjectives with similar meaning. A subject must choose one adjective (out of six) which is closest in meaning to the target word (e.g., LONELY 1. active, 2. sad, 3. hurt, 4. aimless, 5. indifferent, 6 . nothing listed). It is important to emphasize that this test has a correct answer, based on a solution from a Croatian dictionary (Anić, 1994). The test has been used in various research and had shown satisfying psychometric properties, with reliability coefficient $\alpha=.91$ and $44 \%$ of unique variance over and above various tests of standard intelligence (Takšić et al., 2004b). In research, it is also used in combination with EI tests measuring other branches from the Mayer-Salovey model (Babić Čikeš \& Buško, 2015; Hajncl, 2012).

Big Five Inventory (BFI; John \& Srivastava, 1999) uses the Big-Five Factor Markers from the International Personality Item Pool, developed by Goldberg (1992). The test consists of 44 items that participants must rate on how true they are about them on a five-point scale. The questionnaire formed to measure extraversion, conscientiousness, neuroticism, agreeableness, and openness. Benet-Martínez \& John (1998) reported the Cronbach alpha coefficients for extraversion .88, conscientiousness .84, agreeableness .79, neuroticism .82 and openness .81 .

Test of Series (TS-10, Pogačnik, 1997) is developed for measuring fluid intelligence according to the Cattell - Horn theory of intelligence. The short form of the test consists of 30 nonverbal items. In each task, on the left, there is an unfinished series of characters and on the right, there are five suggested solutions among which only one character continues the sequence correctly. The number of correct answers is calculated by subtracting a quarter of incorrectly solved tasks from the number of correctly solved tasks.

Multifactor Leadership Questionnaire (MLQ-X5, Bass \& Avolio, 2000) is the instrument for assessing transformational and transactional leadership behaviour as an integral part of the Bass's Full Range Leadership Model. The MLQ is widely accepted and used. Extensive research highlights its validity and reliability to measure management behaviour (Lowe, Kroek, \& Sivasubramaniam, 1996). This instrument was translated into Croatian language (Avolio \& Bass, 2010). The MLQ is provided in 2 forms: Self and Raters (how the participants view themselves and how they are viewed by their subordinates). The five subscales asses transformational leadership behaviours (e.g., I re-examine critical assumptions to question whether they are appropriate.), three subscales asses transactional leadership style (e.g., I make clear what one can expect to receive when performance goals are achieved.), one laissez-faire (e.g., I avoid making decisions.), and three outcome scales in the MLQ-5X are included. In this study, we analysed and provided psychometric properties for the TL style taken as a general measure of all five TL scales. 


\section{Procedure}

The administration of the tests and questionnaires was carried out in the organizational settings. VET-3, ESCQ-45, TS-10, and BFI were applied to 177 participants (leaders) to evaluate their level of EI, fluid mental ability and five factors of personality. After that, leaders completed MLQ self-form to rate their leadership styles. The participants were granted anonymity, and they received no compensation for their participation.

\section{Results}

To evaluate whether ESCQ-45 scores were redundant with Big Five and whether VET-3 was redundant with fluid ability, correlations between all scales were examined. Table 2 shows a significant but moderate correlation between ESCQ-45 and Big Five dimensions.

Table 2

Means, Standard Deviation, Range and Coefficients of Reliability for All Measured Variables $(N=177)$

\begin{tabular}{lrrrrrc}
\hline Variables & $k$ & Min & Max & $M$ & $S D$ & $\begin{array}{c}\text { Cronbach } \\
\text { alpha }\end{array}$ \\
\hline ESCQ-45 & 45 & 122 & 215 & 169.05 & 15.49 & .91 \\
ESCQ-M & 16 & 49 & 77 & 62.23 & 5.56 & .71 \\
ESCQ-E & 14 & 35 & 68 & 52.28 & 6.04 & .82 \\
ESCQ-P & 15 & 27 & 75 & 54.36 & 7.32 & .90 \\
VET-3 & 102 & 38 & 97 & 78.99 & 10.76 & .88 \\
BIG-E & 15 & 22 & 45 & 32.69 & 4.45 & .63 \\
BIG-A & 15 & 25 & 42 & 35.13 & 3.97 & .63 \\
BIG-C & 15 & 20 & 45 & 32.77 & 4.06 & .74 \\
BIG-ES & 15 & 14 & 40 & 28.79 & 4.90 & .80 \\
BIG-O & 14 & 20 & 45 & 33.27 & 4.73 & .78 \\
TS-10 & 30 & 0 & 30 & 16.99 & 5.88 & .83 \\
MLQ-TL & 20 & 34 & 80 & 59.12 & 7.65 & .85 \\
\hline
\end{tabular}

Note. $k=$ number of items; ESCQ-45 (M, E, P) = The Emotional Skills and Competence Questionnaire45, (M - Manage emotions, E - Expressing emotions, $\mathrm{P}$ - Perceiving emotions); VET-3 = Vocabulary emotions test-3; BIG-E, A, C, ES, O = The Big-five Personality Item Pool (E - Extroversion, A Agreeableness, C - Consciousness, ES - Emotional stability, O - Openness); TS-10 = Test of series-10; MLQ-T = Multifactor Leadership Questionnaire-Transformational style self-ratings. 
Table 3

Bivariate Correlation between All Variables in the Study

\begin{tabular}{lcccccccccccc}
\hline & 1 & 2 & 3 & 4 & 5 & 6 & 7 & 8 & 9 & 10 & 11 & 12 \\
\hline 1. TS-10 & - & $.22^{* *}$ & -.13 & .02 & -.13 & $-.17^{*}$ & -.04 & -.14 & -.14 & -.07 & .00 & -.11 \\
2. VET-3 & - & -.00 & -.01 & -.01 & .00 & .08 & .00 & .02 & .12 & .04 & -.05 \\
3. ESCQ-45 & & - & $.77^{* *}$ & $.83^{* *}$ & $.84^{* *}$ & $.48^{* *}$ & $.18^{*}$ & $.49^{* *}$ & $.39^{* *}$ & $.44^{* *}$ & $.41^{* *}$ \\
4. ESCQ-M & & & - & $.52^{* *}$ & $.44^{* *}$ & $.44^{* *}$ & $.18^{*}$ & $.35^{* *}$ & $.45^{* *}$ & $.41^{* *}$ & $.32^{* *}$ \\
5. ESCQ-E & & & & - & $.54^{* *}$ & $.44^{* *}$ & .14 & $.39^{* *}$ & $.29^{* *}$ & $.35^{* *}$ & $.24^{* *}$ \\
6. ESCQ-P & & & & & - & $.32^{* *}$ & .13 & $.44^{* *}$ & $.24^{* *}$ & $.33^{* *}$ & $.43^{* *}$ \\
7. BIG-E & & & & & & - & .04 & $.39^{* *}$ & $.34^{* *}$ & $.62^{* *}$ & $.32^{* *}$ \\
8. BIG-A & & & & & & & - & $.31^{* *}$ & $.40^{* *}$ & $.16^{*}$ & $.18^{*}$ \\
9. BIG-C & & & & & & & & - & $.42^{* *}$ & $.45^{* *}$ & $.44^{* *}$ \\
10. BIG-ES & & & & & & & & & - & $.24^{* *}$ & $.18^{*}$ \\
11. BIG-O & & & & & & & & & & - & $.41^{* *}$ \\
12. MLQ - TL & & & & & & & & & & & - \\
\hline
\end{tabular}

Note. ESCQ-45 (M, E, P) = The Emotional Skills and Competence Questionnaire-45, (M - Manage emotions, E - Expressing emotions, P - Perceiving emotions); VET-3 =Vocabulary emotions test-3; BIG-E, A, C, ES, O = The Big-five Personality Item Pool (E - Extroversion, A - Agreeableness, C Consciousness, ES - Emotional stability, O - Openness); TS-10 = Test of series -10; MLQ-TL = Multifactor Leadership Questionnaire-Transformational style self-ratings; ${ }^{*} p<.05 ;{ }^{* * *} p<.01$.

There was a low correlation between the ability-based test of EI VET-3 and the test of cognitive ability TS-10. These findings are in line with previous studies, where ability-based tests of EI were mostly independent of personality and intelligence (Takšić et al., 2004b). The VET-3 has strong discriminant validity from Big Five personality dimensions, and low with fluid cognitive ability. The ESCQ-45 has moderate discriminant validity from the personality dimensions, but there was no correlation between ESCQ-45 and VET-3 or even TN-10.

Table 4

Hierarchical Regression Analysis for the Leader's Self-Ratings of Transformational Style as a Criterion Variable

\begin{tabular}{lcccc}
\hline & \multicolumn{3}{c}{ Self-ratings of transformational leadership } \\
\hline Predictors & $R$ & $R^{2}$ & $\Delta R$ & $\beta$ \\
\hline 1. Step & & & & \\
Demographic & .17 & .04 & .04 & -.13 \\
Age & & & .11 \\
Gender & & & .06 \\
Education & & & \\
2. step & .24 & .06 & .01 & -.09 \\
Intelligence & & & \\
General mental ability & & & \\
\hline
\end{tabular}


PSYCHOLOGICAL TOPICS, 29 (2020), 1, 119-134

\begin{tabular}{lcccc}
\hline \multicolumn{5}{c}{ Self-ratings of transformational leadership } \\
\hline Predictors & $R$ & $R^{2}$ & $\Delta R$ & $\beta$ \\
\hline 3. Step & & & \\
Personality traits & .51 & $.26^{* *}$ & $.21^{* *}$ & \\
Extraversion & & & .05 \\
Emotional stability & & & -.06 \\
Consciousness & & & $.28^{* *}$ \\
Agreeableness & & & .07 \\
Openness & & & $.24^{* *}$ \\
\hline 4. step & & & .01 & -.08 \\
VET-3 & .51 & $.05^{* *}$ & .09 \\
\hline 5. step & & & -.14 \\
ESCQ- M & .58 & & $.24^{* *}$ \\
ESCQ- E & & & $F=5.83^{* *}$ \\
ESCQ -P & & & \\
\hline
\end{tabular}

Note. Gender $0=$ Male, $1=$ Female $;{ }^{* *} p<.01$.

The result of hierarchical regression analysis for the self-assessment criterion of the TL leadership style indicates that the selected set of predictors explain $34 \%$ of the variance of TF leadership style. The largest and statistically most significant independent contribution in the explanation of TL style variance can be attributed to the set of personality traits, among which the highest values had dimensions of conscientiousness $(\beta=.28 ; p<.01)$ and openness to experiences $(\beta=.24 ; p<.01)$. The set of EI variables also show a statistically significant, but also theoretically significant, independent contribution $(\Delta R=4.89 ; p<.01)$. EI explains a total of $5 \%$ variance for TL leadership style, with statistically significant and positive beta weight for the subscale Perception and emotion understanding from the ESCQ-45 emotional competence scale $(\beta=.29 ; p<.01)$.

\section{Discussion}

The major purpose of the present study was to investigate whether EI operationalized as a performance-based ability test or as a self-report scale of ability to understand emotions can explain unique variance in predicting TL style above and beyond personality traits and cognitive ability. The results show that this regression equation model including age, sex, educational level (general demographic features), Big Five personality traits, cognitive intelligence, and emotional intelligence variables can explain approximately $34 \%$ of the criterion variance for the self-report measure of TL style. Personality traits of conscientiousness and openness to experience, as well as EI dimension named perceiving and understanding emotions, 
showed a considerable additive contribution on the unique criterion variance, whereas the role of verbal understanding of emotional content (ability test of EI) within the predictor structure examined proved to be statistically insignificant.

\section{Predictive Validity of the Self-Report Scale of Emotional Intelligence and Transformational Leadership}

ESCQ-45 is based on strong theoretical foundations, which considers EI a stable variable with individual differences. The instrument has good psychometric properties, especially reliabilities of the general factor of EI and its sub facets. The ESCQ-45 subscales were moderately correlated with personality traits but are not related to cognitive ability and VET-3. Overall these findings are in accordance with findings of the authors who suggest that EI, measured as the ability to monitor and understand emotions - both others' and our own - may be an underlying competency of TL (Barbuto \& Burbach, 2006; Palmer, Walls, Burgess, \& Stough, 2000). Conceptually, it is possible that perceiving and understanding emotions is an important ability for successful and transformational leadership. This study shows that leaders estimate that those who are good at perceiving and understanding emotions also show more transformational behaviour than others, less emotional competent.

More precisely, when leaders can perceive and understand both their own and others' emotions, they know how to be emotionally close and supportive to their subordinates, enhance their level of trust, motivation, and commitment (Naznin, 2013). The results in the study show that the combination of emotional abilities and personality traits is important for prediction of TL style. This result is in line with McCrae (2000) who argues that the processing of emotional experiences involves specific emotional ability and personality traits. Similar, others found that selfreports capture well the emotions that leaders feel in the leadership process (O'Boyle, Humphrey, Pollack, Hawver, \& Story, 2011). These aspects of EI are identified as core attributes of transformational behaviour. Subsequently, effective leaders may provide additional criteria for identifying a potentially effective leader.

\section{Emotional Intelligence Measured as Performance-Based Ability Test and Transformational Leadership}

A central aspect of the ability-based operationalization of EI is that it is not a collection of personality traits (Mayer \& Salovey, 1997). In this study, VET-3 does not correlate with personality dimensions such as neuroticism, openness, extraversion, agreeableness and conscientiousness. Our ability-based measure of EI has greater discriminant validity with personality traits but it is somewhat related to cognitive ability $(r=.22)$. In line with Weinberger (2004) and Chatterjee and Kulakli (2015) and contrary to our expectation, EI measured as ability was not related to TL. Results of regression analysis show that EI measured as ability from branch $\mathrm{C}$ - the 
understanding of meaning and emotions - has no predictive validity with TL. VET3 is ability-based test close to verbal intelligence (Vučenović \& Hajncl, 2018) and our results prove the other findings that cognitive ability is not a distinct predictor of TL (Bass \& Avolio, 2000; Hajncl \& Vučenović, 2014).

The explanation of different predictive validity of ESCQ-45 and VET-3 with TL could be in construct validity between ESCQ-45 and VET-3. The validity of EI measures is usually evaluated in terms of construct validity, psychometric characteristics of the test or assumed correlation between the examined constructs. The results of a simple correlation analysis indicate that there is no correlation between facets of EI on the ESCQ-45 assessment scale with the measure of EI on the VET-3 test. According to the theory of validity, if the above measures are not related, especially the measure of perception and understanding of emotions with understanding the meaning of emotional words, then measures above do not measure the same construct, which consequently causes a difference in their predictive validity. However, a group of EI researchers cites a serious problem when it comes to measuring EI, regardless of whether it is considered a personality trait or ability. They conclude that the assessment of the validity for individually measured instruments is the biggest limitation in explaining EI (Miners, Côté, \& Lievens, 2018) and suggest that validity should be evaluated in terms of underlying mental processes. The validity between individual measures of EI would then not differ to a great extent, which would allow more systematic and accurate research of EI and consequently, its predictive validity for individual criteria such as TL (Vučenović \& Hajncl, in press). Additionally, different effects of performance-based ability test and self-reported measure of ability EI on self-reported TL might occur because of research methodology. As Harms and Credé (2010) suggested when ratings of both EI and leadership behaviours were provided by the same source the self-report measures of EI tended to show higher validities than ability-based measures of EI related to transformational and other leadership behaviours.

\section{Limitations and Directions for Future Research}

The limitations of the present studies naturally include the probability of response bias resulting from self-reported data. Furthermore, the research methodology was partly cross-sectional and examined the correlation between selfreport predictor variables of EI and personality traits and self-report criterion variable TL (Lievens, Van Geit, \& Coetsier, 1997). Further research needs to focus on using multiple rating sources or objective criterion outcomes of leadership to establish an accurate model that can elucidate the nature of this relationship. Also, future studies should look for possible moderator variables on the relationship between EI and TL such as the role of individual differences between the leaders and the subordinate in specific cultural settings. Specifically, validity between individual EI measures 
requires further investigation as well as their predictive validity for individual criteria, namely transformational leadership.

\section{Conclusion}

The major purpose of the present study was to investigate whether EI, operationalized as performance-based ability test and as a self-report scale of leader's ability to understand own emotions, accounts for unique variance in predicting TL above and beyond personality traits and cognitive ability. We examined the issue by including two measures of EI: ESCQ-45 and VET-3. The results show no predictive validity of VET-3 as the performance-based measure of EI and TL as the criterion variable. Our results provide support for the ESCQ-45 in terms of predictive validity for self-ratings of TL style. The results provide evidence that the ability for perceiving and understanding emotions, operationalized as one competence in selfreported ability scale, offer a significant explanation of TL style after controlling personality traits and cognitive abilities. The personality traits were significant predictors, especially conscientiousness and openness to experience. The present findings confirm that leaders in organizational settings consider those who are good in understanding emotions - both others' and their own - will practice more transformational behaviour than others who do not have the same level of emotional competence. To establish an accurate picture of the nature of these relationships, further research needs to focus more on using multiple ratings sources for leadership behaviour and on new ways of assessing the validity of EI measures in terms of underlying mental processes that would allow systematic and accurate determination of predictive validity EI in explaining the origin of TL style.

\section{References}

Anić, V. (1994). Rječnik hrvatskoga knjževnog jezika [Croatian Dictionary]. Zagreb: Novi liber.

Antonakis, J. (2004). On why „emotional intelligence” will not predict leadership effectiveness beyond IQ or the „Big Five”: An extension and rejoinder. Organizational Analysis, 12(2), 171-182.

Antonakis, J., Ashkanasy, N. M., \& Dasborough, M. T. (2009). Does leadership need emotional intelligence? Leadership Quarterly, 20, 247-261.

Avolio, B. J., \& Bass, B. M. (2010). Višefaktorski upitnik rukovođenja - MLQ priručnik [Multifactor Leadership Questionnaire - MLQ Manual]. Jastrebarsko: Naklada Slap.

Avsec, A., Takšić, V., \& Mohorić, T. (2009). The relationship of trait emotional intelligence with the Big Five in Croatian and Slovene university student sample. Psihološka Obzorja, 18, 99-110. 
Babić Čikeš, A., \& Buško, V. (2015). Emocionalna inteligencija u ranoj adolescenciji: Korelati sposobnosti upravljanja emocijama i predikcija školskog uspjeha [Emotional intelligence in early adolescence: Correlates of emotion management skills and the prediction of school success]. Društvena istraživanja, 24(1), 21-45.

Barbuto, J. E., \& Burbach, M. E. (2006). The emotional intelligence of transformational leaders: A field study of elected officials. The Journal of Social Psychology, 146(1), 5164.

Barling, J., Slater, F., \& Kelloway, E. K. (2000). Transformational leadership and emotional intelligence: An exploratory study. Leadership and Organization Development Journal, 21, 157-161.

Bass, B. M. (1985). Leadership and performance beyond expectations. New York: Free Press.

Bass, B. M. (1990). From transactional to transformational leadership: Leading to share the vision. Organizational Dynamics, 18, 19-36.

Bass, B. M. (1997). Does the transactional-transformational leadership paradigm transcend organizational and national boundaries? American Psychologist, 52(5), 130-139.

Bass, B. M. (2000). Cognitive, social and emotional intelligence of transformational leaders. In R. E. Riggio, S. E. Murphy, \& F. J. Pirozzolo (Eds.), Multiple intelligences and leadership (pp. 105-118). Mahwah, NY: Lawrence Erlbaum Associates.

Bass, B. M., \& Avolio, B. J. (2000). Multifactor leadership questionnaire. Redwood City, CA: Mind Garden.

Benet-Martínez, V., \& John, O. P. (1998). Los Cinco Grandes across cultures and ethnic groups: Multitrait method analyses of the Big Five in Spanish and English. Journal of Personality and Social Psychology, 75, 729-750.

Brown, F. W., \& Moshavi, D. (2005). Transformational leadership and emotional intelligence: A potential pathway for an increased understanding of interpersonal influence. Journal of Organizational Behavior, 26, 867-871.

Butler, C. J., \& Chinowsky, P. S. (2006). Emotional intelligence and leadership behavior in construction executives. Journal of Management in Engineering, 22, 119-25.

Chatterjee, A., \& Kulakli, A. (2015). An empirical investigation of the relationship between emotional intelligence, transactional and transformational leadership styles in banking sector. Procedia - Social and Behavioral Sciences, 210, 291-300.

Ciarrochi, J., Caputi, P., \& Mayer, J. D. (2003). The distinctiveness and utility of a measure of trait emotional awareness. Personality and Individual Differences, 34(8), 1477-1490.

Clarke, N. (2010). Emotional intelligence and its relationship to transformational leadership and key project manager competence. Project Manager Journal, 41(2), 5-20.

Coetzee, C., \& Schaap, P. (2005). The relationship between leadership behavior, outcomes of leadership and emotional intelligence. Journal of Industrial Psychology, 3(3), 31-38.

Cooper, R. K., \& Sawaf, A. (1997). Executive EQ: Emotional intelligence in leadership and organizations. New York: The Berkley Publishing Group. 
Costa, A., Faria, L., \& Takšić, V. (2016). Cross-cultural invariance of Emotional Skills and Competence Questionnaire between Portugal and Croatia. The Spanish Journal of Psychology, 19, 1-12.

Faria, L., Lima Santos, N., Takšić, V., Räty, H., Molander, B., Holmström, S., \& Toyota, H. (2006). Cross-cultural validation of the Emotional Skills and Competence Questionnaire (ESCQ). Psicologia, 20, 95-127.

George, J. M. (2000). Emotions and leadership: The role of emotional intelligence. Human Relations, 53(8), 1027-1055.

Goldberg, L. R. (1992). The development of markers for the Big-Five factor structure. Psychological Assessment, 4(1), 26-42.

Groves, K. S. (2006). Leader emotional expressivity, visionary leadership, and organizational change. Leadership and Organization Development Journal, 2, 566-583.

Hajncl, Lj. (2012). Emocionalna inteligencija i stilovi rukovođenja [Emotional intelligence and leadership styles]. (Unpublished doctoral dissertation). Faculty of Humanities and Social Sciences, University of Zagreb, Zagreb.

Hajncl, Lj., \& Vučenović, D. (2013). Emocionalna inteligencija: Modeli i mjerenje 20 godina poslije [Emotional intelligence: Models and measurement 20 years later]. Suvremena psihologija, 16(1), 95-113.

Hajncl, Lj., \& Vučenović, D. (2014). Odnos opće mentalne sposobnosti, osobina ličnosti i transformacijskog stila rukovođenja: Uloga izvora procjene [Relationship between general mental ability, personality traits and transformational leadership style: The role of the source of assessment]. Psihologijske teme, 23(3), 369-387.

Harms, P. D., \& Credé, M. (2010). Emotional intelligence and transformational and transactional leadership: A meta-analysis. Leadership Institute Faculty Publications, 14, $5-17$.

John, O. P., \& Srivastava, S. (1999). The big five trait taxonomy: History, measurement, and theoretical perspectives. In L. A. Pervin \& O. P. John (Eds.), Handbook of personality: Theory and research (pp. 102-138). New York: Guilford.

Jordan, P. J., Ashkanasy, N. M., Hartel, C. E., \& Hooper, G. S. (2002). Workgroup emotional intelligence: Scale development and relationship to team process, effectiveness, and goal focus. Human Resource Management Review, 12, 195-214.

Joseph, D. L., \& Newman, D. A. (2010). Emotional intelligence: An integrative meta-analysis and cascading model. Journal of Applied Psychology, 1, 54-78.

Judge, T. A., \& Piccolo, R. F. (2004). Transformational and transactional leadership: A metaanalytic test of their relative validity. Journal of Applied Psychology, 89(5), 755-768.

Kim, H., \& Kim, T. (2017). Emotional intelligence and transformational leadership: A review of empirical studies. Human Resource Development Review, 16(1), 153448431772926. 
Kulenović, A., Balenović, T., \& Buško, V. (2000). Test analize emocija: Jedan pokušaj objektivnog mjerenja sposobnosti emocionalne inteligencije [The test of emotion analysis: One attempt to objectively measure the ability of emotional intelligence]. Suvremena psihologija, 3, 27-48.

Küypers, W., \& Wiebler, J. (2006). How emotional is transformational leadership really? Some suggestions for a necessary extension. Leadership and Development Journal, 27, 363-383.

Lam, C., \& O’Higgins, E. (2013). Emotional intelligence and leadership styles in China. Asia Pacific Management Review, 18(4), 441-467.

Leban, W., \& Zulauf, C. (2004). Linking emotional intelligence abilities and transformational leadership styles. The Leadership \& Organization Development Journal, 25(7), 554564.

Lievens, F., Van Geit, P., \& Coetsier, P. (1997). Identification of transformational leadership qualities: An examination of potential biases. European Journal of Work and Organizational Psychology, 6, 415-430.

Lowe, K. B., Kroeck, K. G., \& Sivasubramaniam, N. (1996). Effectiveness correlates of transformation and transaction leadership: A meta-analytic review of the MLQ literature. Leadership Quarterly, 7, 385-425.

Mandell, B., \& Pherwani, S. (2003). Relationship between emotional intelligence and transformational leadership style: A gender comparison. Journal of Business and Psychology, 17(3), 387-404.

Mayer, J. D., \& Salovey, P. (1997). What is emotional intelligence?. In P. Salovey \& D. Sluyter (Eds.), Emotional development and emotional intelligence: Implications for educators (pp. 3-31). New York: Basic Books.

Mayer, J. D., Caruso, D. R., \& Salovey, P. (1999). Emotional intelligence meets traditional standards for an intelligence. Intelligence, 24(4), 267-298.

Mayer, J. D., Caruso, D. R., \& Salovey, P. (2004). Emotional intelligence: Theory, practice, and implications. Psychology Inquiry, 15, 197-215.

McCrae, R. R. (2000). Trait psychology and the revival of personality and culture studies. American Behavioral Scientist, 44, 10-31.

Miners, T. H., Côté, S., \& Lievens, F. (2018). Assessing the validity of EI measures. Emotion Review, 10(1), 87-95.

Mohorić, T. (2012). Razumijevanje emocija kao komponenta emocionalne inteligencije u ranoj adolescenciji [Understanding emotions as a component of emotional intelligence in early adolescence]. (Unpublished doctoral dissertation). Faculty of Humanities and Social Sciences, University of Zagreb, Zagreb.

Mohorić, T., \& Takšić, V. (2016, May). DIF analysis of ESCQ using Mantel-Haenszel method: Cross-cultural comparison. Paper presented at XX. Days of psychology, Zadar, Croatia. 
Molander, B., Holmström, S., \& Takšić, V. (2011). South and North: DIF analysis of university-student responses to the Emotional Skills and Competence Questionnaire. Psychological Topics, 3, 425-447.

Naznin, H. (2013). Correlation between emotional intelligence and transformational leadership behaviour. Journal of Business and Management, 13(2), 64-67.

O’Boyle, E. H. Jr., Humphrey, R. H., Pollack, J. M., Hawver, T. H., \& Story, P. A. (2011). The relation between emotional intelligence and job performance: A meta-analysis. Journal of Organizational Behavior, 32, 788-818.

Palmer, B., Walls, M., Burgess, Z., \& Stough, C. (2000). Emotional intelligence and effective leaderhsip. Leadership \& Organization Development Journal, 22(1), 5-10.

Pogačnik, V. (1997). Priručnik za Test nizova [Test series Manual]. Jastrebarsko: Naklada Slap.

Salovey, P., \& Mayer, J. D. (1990). Emotional intelligence. Imagination, Cognition and Personality, 9(3), 185-211.

Spano-Szekely, L., Quinn Griffin, M. T., Clavelle, J., \& Fitzpatrick, J. J. (2016). Emotional intelligence and transformational leadership in nurse managers. The Journal of Nursing Administration, 46(2), 101-108.

Takšić, V. (1998). Validacija konstrukta emocionalne inteligencije [Validation of the construct of emotional intelligence]. (Unpublished doctoral dissertation). Faculty of Humanities and Social Sciences, University of Zagreb, Zagreb.

Takšić, V. (2002). The questionnaires of emotional intelligence and competence. In K. Lacković Grgin, A. Proroković, V. Ćubela, \& Z. Penezić (Eds.), Psychological scales and questionnaires (pp. 27-41). Zadar: University of Zadar.

Takšić, V., Harambašić, D., \& Velemir, B. (2004a, July). Vocabulary Emotions Test (VET): Contribution to divergent validity of emotional intelligence. Paper presented on International congress in Psychology, Beijing, China.

Takšić, V., Harambašić, D., \& Velemir, B. (2004b). Emotional Vocabulary Test as an attempt to measure the emotional intelligence ability - understanding emotion aspect. International Journal of Psychology, 39, 5-6.

Takšić, V., Mohorić, T., \& Duran, M. (2009). Emotional Skills and Competence Questionnaire (ESCQ) as a self-report measure of emotional intelligence. Horizons of Psychology, 18, 7-21.

Takšić, V., Mohorić, T., \& Holmström, S. (2018). Cross-cultural studies of trait emotional intelligence using the Emotional Skills and Competence Questionnaire (ESCQ). In M. del Carmen Pérez Fuentes, M. del Mar Molero Jurado, \& J. J. Gázquez Linares (Eds), Emotional intelligence: Perceptions, interpretations and attitudes (pp. 29-64). New York: Nova Science Publishers, Inc.

Vučenović, D., \& Hajncl, Lj. (2018). Effects of the age in the relationship between verbal and nonverbal abilities and emotional intelligence. Suvremena psihologija, 21(2), 121-139. 
Vučenović, D., \& Hajncl, Lj. (in press). Determining latent dimensions and relationship between intelligence, ability emotional intelligence and trait emotional intelligence. Suvremena psihologija, 22.

Webb, S. (2004). Exploring the relationship of emotional intelligence to transformational leadership within mentoring relationships (Master's thesis). Department of Psychology, University of South Florida, Tampa.

Weinberger, L. A. (2004, March). An examination of the relationship between emotional intelligence and leadership style. Paper presented at the Academy of Human Resource Development International Conference, Austin, TX.

Wong, C. S, Wong, P. M., \& Law, K. S. (2007). Evidence on the practical utility of Wong's emotional intelligence scale in Hong Kong and Mainland China. Asia Pacific Journal of Management, 24, 43-60.

Received: October 22, 2019 